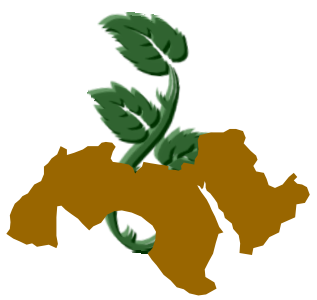

Arab Univ. J. Agric. Sci., Ain Shams Univ., Cairo, 16(2), 389-397, 2008

\title{
PRODUCTION AND EVALUATION OF NUTRACEUTICAL VEGETABLE JUICE BLENDS
}

\author{
El-Bastawesy Amal ${ }^{1}$, M.; Lobna A.M. Hareedy ${ }^{1}$ and W.A. El-Malky ${ }^{2}$ \\ 1- Food Technology Res. Institute, Agric. Res. Center, Giza, Egypt \\ 2- Drug Food Dept. National Organization for Drug Control and Research (NODCAR), Gi- \\ za, Egypt
}

Keywords: Vegetable juices, Juice blends, Healthy juices, Antioxidant compounds

\section{ABSTRACT}

A great interest has been recently focused on vegetable juices. So, this study was made as a trial to produce new untraditional vegetable juice blends with high balanced nutritive value. Thirteen different pasteurized vegetable juice blends were prepared. Four blends were only selected representing the most favorite ones, which were preferred by the panelists. The chosen blends were stored at $5 \pm 1^{\circ} \mathrm{C}$ for 3 months during which, the chemical composition, antioxidants activity as well as the microbial examination were carried out. The chemical composition of all selected blends was approximately similar except for blend 11 (carrot, watermelon, pumpkin, celery and parsley) having the lowest value of total acidity $(0.054 \%)$ compared to the other blends. No significant differences were detected between the total phenolic compounds of those four blends and the control (imported commercial vegetable juice). Blend (4), (tomato, carrot and celery) had the highest contents of total phenols and total flavonoids being 16.65 and $31.25 \mathrm{mg}$ $1100 \mathrm{ml}$, respectively. Total carotenoids of all blends ranged from 7.69 to $12.09 \mathrm{mg} / 100 \mathrm{ml}$. Addition of green leafy vegetables (celery and parsley) to blend (11) increased total chlorophyll content by more than two folds becoming greater (52.43 $\mathrm{mg} / 100 \mathrm{gm}$ ) than the other studied blends as well as the control sample. Meanwhile, ascorbic acid content ranged from 8.45 to $20.22 \mathrm{mg} / 100 \mathrm{ml}$. Blend (3),( tomato, carrot, watermelon and rocket ) had the highest content of ascorbic acid, meanwhile, blend (11), being free from tomato juice, had the lowest content. All selected blends had ade- quate minerals contents and could be considered sufficient sources of minerals to human nutrition. Also, insignificant differences in chemical composition of the selected vegetable juice blends could be detected throughout the storage period. On the other hand, the thermal treatments, blanching and pasteurization reduced the activity of microorganisms and all products maintained their original sensory properties.

\section{INTRODUCTION}

Vegetables are rich sources of a variety of nutrients, including vitamins, trace elements and dietary fibers, which are very important in the diet ingredients and play a great role in human nutrition. Vegetables contain also other biologically active compounds such as, carotenoids, flavonoids, phenols, indoles and plant sterols. Also, vegetables are rich sources of micronutrients with antioxidative properties including the antioxidant vitamins $C, E$ and $\beta$-Carotene (Steinmetz and Potter 1991). Those phytochemicals can have complementary and overlapping mechanisms of action, including modulation of detoxification enzymes, stimulation of the immune system, reduction of platelet aggregation, and modulation of cholesterol synthesis and hormone metabolism. The aforementioned compounds also can reduce blood pressure, inhibit the formation of nitrosamine and bind with carcinogens in the digestive tract (Steinmetz and Potter 1991 and Johanna 1999). Moreover, the consumption of vegetable juices predicts a reduced risk of Alzheimer's disease (Amy et al 2005). High consumption vegetables was associated with reduced global cognitive decline during up to 6 years of observation in a community of over 3000 older persons (Morris et al 2006) Furthermore, all vegetable juices inhibit the 
degradation of dioxyribose and increased the viability of $\mathrm{H}_{2} \mathrm{O}_{2}$ treated cells (Marco et al 2002). Therefore, fresh vegetable juices have become a new functional food for healthy nutrition. Green leafy vegetables are considered to be among the most popular ones grown in Egypt and usually consumed either in the fresh form as salads or as processed products. Also, green vegetable juices can be used regularly to supply consumers with chlorophyll, minerals and vitamins. Tomatoes and carrots are considered the main two vegetable crops either for local consumption or for export. Their juices are suitable sources of vitamins, sugars and minerals and also consumed for their excellent organoleptic properties. Tomatoes contain lycopene, a stable active antioxidant, and carrots are rich in $\beta$-carotene, a precursor of vitamin $A$ (Djuric and Powell 2001). Sook Lee et al (2003) illustrated that lycopene is the compound responsible for the red color in tomato and watermelon. A great interest has been recently focused on lycopene due to its preventive activity against several pathologies, such as cardiovascular disease (Rao, 2002) and some cancer types (Shi and Le Maguer 2000). Also, consumption of tomato or tomato products has been associated with decreased risk of some cancer. In addition to lycopene, polyphenols present in tomatoes, may be important in conferring protective antioxidative effects (Takeoka et al 2001). It is also important to consider the synergic action of carotenoids with other bioactive compounds present in fruits and vegetables. Some carotenoids, besides being provitamin A activity, have other functions such as, antioxidative effect, enhancers of the immune response and some of them are involved in the cell communication. These properties together with epidemiological studies established a relation between a high vegetable intake and a lower risk of chronic degenerative diseases, such as certain types of cancer or cardiovascular diseases (Ruel et al 2005 and Rodriguez-Bernaldo and Costa 2006). Moreover, many vegetables contain quercetin and related polyphenolic compounds. Antioxidants in foods can control the oxidation process reactions in the body with possible adverse consequences. Also, even ageing and longevity in good health would be favoured by the availability of adequate amount of varied antioxidants (Weisburger 1999 and Ruel et al 2005). Accordingly, this study was an attempt to produce and evaluate new nutraceutical vegetable juice blends with good balanced nutritive value and high preference among different consumers.

\section{a- Materials}

- Four fresh vegetables namely, tomatoes, watermelon, carrots and pumpkin as well as four green leafy vegetables namely, spinach, garden rocket, celery and parsley were obtained from a private farm in Giza Governorate, Egypt.

- V8 an imported commercial vegetable juice as a control.

\section{b- Methods}

\section{1- Preparation of vegetable juices}

All vegetables were sorted, washed (carrots and pumpkin were peeled), then cut into small pieces and blanched at $90^{\circ} \mathrm{C}$ for $10 \mathrm{~min}$. except the watermelon. Vegetables were blended in a blender and the juices were strained through muslin cloth.

\section{2 - Preparation of vegetable blends}

Vegetable juices were mixed with different ratios as shown in Table (1) to make thirteen different blends and $0.1 \%$ sodium chloride was added during mixing to all blends except for blend (11). The obtained blends were filled into glass bottles, pasteurized at $90^{\circ} \mathrm{C}$ for $10 \mathrm{~min}$., cooled at room temperature and stored in refrigerator at $5 \pm 1^{\circ} \mathrm{C}$ for 3 months.

\section{3 - Analytical methods}

- Moisture, ash, total carbohydrates, crude protein and crude fibers contents were determined according to the A.O.A.C. (1998).

- Total soluble solids, total acidity, Brix degree and specific gravity were determined by the methods described by Ranganna (1979).

- Antioxidant compounds: ascorbic acid, total carotenoids, phenols, flavonoids and chlorophyll contents were determined by the methods described by Ranganna (1979).

- $\mathrm{pH}$ values were measured at $25^{\circ} \mathrm{C}$ using $\mathrm{pH}$ meter (Fisher Accument), Model (825MP). Minerals (Iron, calcium, potassium, sodium, magnesium, zinc and phosphorus) were determined by dry ashing using atomic absorption PYe Unican Spectrophotometer Sp. England, as mentioned by Kasai et al (1997).

MATERIALS AND METHODS 
Table 1. Vegetable blends composition

\begin{tabular}{|l|c|c|c|c|c|c|c|c|}
\hline Vegetables & Tomato & Carrot & $\begin{array}{r}\text { Water } \\
\text { melon }\end{array}$ & Pumpkin & Spinach & Rocket & Celery & Parsley \\
\cline { 2 - 8 } & \multicolumn{7}{|c|}{ Ratios of Blend } \\
Blend (1) & 5 & 3 & - & - & 1 & - & 1 & - \\
Blend (2) & 5 & 2 & 2 & - & - & - & 1 & - \\
Blend (3) & 5 & 2 & 2 & - & - & 1 & - & - \\
Blend (4) & 5 & 4 & - & - & - & - & 1 & - \\
Blend (5) & 5 & 2 & 2 & - & - & - & 1 & - \\
Blend (6) & 5 & 4 & - & - & - & - & - & 1 \\
Blend (7) & 5 & 2 & - & 2 & 1 & - & - & - \\
Blend (8) & 5 & - & - & 4 & - & - & 1 & - \\
Blend (10) & 3 & 5 & 1 & - & - & - & - & 1 \\
Blend (11) & 4 & 1 & - & 4 & 1 & - & - & - \\
Blend (12) & - & 4 & 2 & 2 & - & - & 1 & 1 \\
Blend (13) & - & 4 & 2 & 1 & 1 & - & 1 & 1 \\
\hline
\end{tabular}

\section{4- Sensory properties}

Sensory attributes (color, taste, odor, texture and overall palatability) of the studied vegetable blends were evaluated directly after preparation by more than ten panelists (chosen by random) in the Food Tech. Res. Inst. according to the method of Lindley et al (1993).

\section{5- Microbiological examination}

Total mesophilic bacterial count, coliform and molds and yeast were determined according to Vonderzant and Splittstoesser (1992).

\section{6- Statistical analysis}

The results were analyzed by analysis of variance (ANOVA) using the procedure by Statistical Analysis System (SAS) program according to Steel and Torrie (1980). Significant differences were determined at the level $p \geq 0.05$.

\section{RESULTS AND DISCUSSION}

\section{1- Sensory evaluation of vegetable juice blends}

Thirteen different pasteurized vegetable juice blends were prepared as mentioned before in Table (1). These blends were sensory evaluated for color, taste, odor, texture and overall, acceptability. From this evaluation, the best blends having the highest palatability were selected to continue the investigation. Imported commercial vegetable juice was used as a control sample and the data are shown in Table (2). The main ingredients of all blends are tomato and carrot juices adhering in higher ratios. Therefore, from data in Table (2), it could be clearly observed that addition of carrot juice by the ratios of 4 and 5 gave the best color and taste of produced blends (6, 4,3,11 and 9, respectively). Although, increasing the carrot's level improved the color and taste of all blends but the values of texture were slightly decreased. In addition, increasing the carrot ratio in the blend increased the consistency and palatability of blends. These results are in agreement with those of Ninnart et al (2002), who reported that an increase for juice in mixed vegetable drinks resulted significantly higher color and cloud stability of the mixed juices that were altered significantly with high quantities of carrot juice. In addition, they reported that, increasing the pumpkin content significantly increased the viscosity but decreased the color's value. From the same table, it could be reported that blend (3), which contained tomato, carrot, watermelon and garden rocket juices with the ratios of $(5: 2: 2: 1)$, had the highest scores of color, taste, odor, texture and overall acceptability followed by blends 4,11 then 6 compared to those of the control sample (exported commercial vegetable juice). Also, it was clearly noticed that blends 
6, 3, 4 and 11 had the highest overall acceptability scores $(6.98,6.95,6.94$ and 6.92, respectively) (Table 2). Finally, from the aforementioned data, it could be concluded that blends 3, 4, 6 and11 had the highest scores and were preferred by the consumers. So, these four blends were selected being the most favorite ones and were stored at $\left(5 \pm 1^{\circ} \mathrm{C}\right)$ up to 3 months for analysis.

\section{2- Chemical composition of selected vegetable juices blends}

Data presented in Table (3) show the chemical composition of selected vegetable juice blends, which had the highest organoleptic scores. From the same table, it could be noticed that, moisture content was the same in the four blends as well as the control sample (imported commercial vegetable juice). Blends 4 and 6 had approximately the same values for all chemical composition except for crude protein, which was slightly increased from 1 to $1.40 \%$ for blends 4 and 6 , respectively (Table 3). Crude fibers content in blend (3) decreased compared to the other selected blends and the control sample. Meanwhile, ash content in blends 4 and 6 was higher than that of blends 3 and 11 (0.60; $0.60 \%$ and $0.40 ; 0.40 \%$, respectively) and their contents were twice than of the control sample. Finally, it could be concluded that the chemical composition of all selected blends were approximately similar except for blend (11) which had the lowest value of total acidity $(0.054 \%)$. This may be due to the absence of tomato juice, which is the main cause of high total acidity in the other blends (Abdel-Latif, 1995). On the other hand, carrots, watermelon and pumpkin juices had lower total acidity (Ninnart et al 2002 and EL-Bastawesy et al 2003). These results are in agreement with those of Ninnart et al (2002), who found that an increase in the amount of pumpkin juice in mixed vegetable drinks resulted in significantly higher $\mathrm{pH}$ value but lower total soluble solids and titratable acidity.

\section{3- Antioxidants content of the selected vegeta- ble juice blends}

Antioxidant compounds of selected vegetable juice blends were also determined and the results are illustrated in Table (4). The aforementioned data show no significant differences among those four blends and control sample for total phenols content. Blend (4) had the highest values of total phenols and total flavonoids (16.65 and $31.25 \mathrm{mg}$ $/ 100 \mathrm{ml}$, respectively). This may be due to the presence of carrot juice in this blend by a ratio of 4 to 5 and $1(\mathrm{v} / \mathrm{v})$ for tomato and celery juices containing significant amounts of phenolic compounds (KähkÖnen et al 1999). On the other hand, both total phenols and flavonoids contents decreased in blend (11) due to the absence of tomato juice from this blend. Total carotenoids of all blends ranged from 7.40 to $12.09 \mathrm{mg} / 100 \mathrm{ml}$. The highest carotenoids contents (12.09 and $9.39 \mathrm{mg} / 100 \mathrm{ml})$ were found in blends 11 and 3 , respectively. This could be attributed to carrot, pumpkin, watermelon and tomato juices which are the main sources of carotenoids. These results are in agreement with those reported by Barba-Olives et al (2006), who found that tomato and watermelon are high lycopene sources with contents ranging from 2.8 to 7.3 $\mathrm{mg} / 100 \mathrm{gm}$ representing $82-87 \%$ of the total carotenoids content in tomato and 87-99\% in watermelon. Also, $\beta$-carotene was found in the highest levels in carrots $(6.3-9.6 \mathrm{mg} / 100 \mathrm{~g})$.Addition of green leafy vegetables (celery and parsley) to blend (11) increased total chlorophyll content by more than two folds greater (52.43 $\mathrm{mg} / 100 \mathrm{gm})$ than the other studied blends as well as the control sample (Table 4). From the same table it could be also concluded that, ascorbic acid content ranged from 8.45 to $20.22 \mathrm{mg} / 100 \mathrm{ml}$. On the other hand, blend (3) had the highest content of ascorbic acid, meanwhile, blend (11) being free from tomato juice, had the lowest content.

\section{4- Minerals content of selected vegetable juice blends}

The data presented in Table (5) show the minerals content of the selected vegetable juice blends. Iron, calcium, potassium, sodium, magnesium, zinc and phosphorus were detected and the obtained results revealed that, potassium and sodium, the major minerals detected in all selected blends, were ranging from 2644 to 3727 and 1518 to $3135 \mathrm{ppm}$, respectively. Magnesium and calcium were found in high amounts compared to iron and zinc, which were in small amounts (Table 5). From the same table, it could be noticed that, blend (4) containing tomato, carrot and celery with a ratio of (5: 4:1) had the highest contents of all minerals except for sodium which recorded the lowest level. This could be due to its content of carrot and celery, which are rich sources of calcium, potassium and magnesium (Ninnart et al 2002 and EL-Bastawesy et al 2003). Blend (6) had higher contents of potassium, zinc, phosphorus and iron than those of blend (11). Contrarily, to the mineral components of blend (11), calcium and 
Table 2. Sensory evaluation of some vegetable juices blends

\begin{tabular}{|c|c|c|c|c|c|}
\hline Properties & $\begin{array}{c}\text { Color } \\
10\end{array}$ & $\begin{array}{c}\text { Taste } \\
\text { Blends }\end{array}$ & $\begin{array}{c}\text { Odor } \\
10\end{array}$ & $\begin{array}{c}\text { Texture } \\
10\end{array}$ & $\begin{array}{c}\text { General } \\
\text { acceptability } \\
10\end{array}$ \\
\hline Control V8 & $7.13 \pm 1.47^{\mathrm{ab}}$ & $6.83 \pm 1.40^{\mathrm{ab}}$ & $7.57 \pm 1.55^{\mathrm{a}}$ & $7.42 \pm 1.38^{\mathrm{a}}$ & $7.18 \pm 1.86^{\mathrm{a}}$ \\
Blend (1) & $6.25 \pm 1.29^{\mathrm{b}}$ & $5.63 \pm 0.74^{\mathrm{bc}}$ & $5.64 \pm 1.03^{\mathrm{c}}$ & $6.50 \pm 1.16^{\mathrm{b}}$ & $6.06 \pm 0.81^{\mathrm{b}}$ \\
Blend (2) & $7.04 \pm 1.42^{\mathrm{ab}}$ & $6.57 \pm 1.51^{\mathrm{ab}}$ & $6.67 \pm 1.32^{\mathrm{b}}$ & $6.79 \pm 1.47^{\mathrm{ab}}$ & $6.64 \pm 1.12^{\mathrm{ab}}$ \\
Blend (3) & $7.54 \pm 1.16^{\mathrm{a}}$ & $7.14 \pm 1.46^{\mathrm{a}}$ & $7.23 \pm 1.72^{\mathrm{a}}$ & $7.33 \pm 1.38^{\mathrm{a}}$ & $6.95 \pm 1.49^{\mathrm{a}}$ \\
Blend (4) & $7.58 \pm 1.02^{\mathrm{a}}$ & $6.57 \pm 1.51^{\mathrm{ab}}$ & $7.36 \pm 1.57^{\mathrm{a}}$ & $7.08 \pm 1.64^{\mathrm{a}}$ & $6.94 \pm 1.63^{\mathrm{a}}$ \\
Blend (5) & $7.25 \pm 1.53^{\mathrm{ab}}$ & $6.50 \pm 1.26^{\mathrm{ab}}$ & $6.09 \pm 1.04^{\mathrm{bc}}$ & $6.54 \pm 1.27^{\mathrm{ab}}$ & $6.30 \pm 1.36^{\mathrm{b}}$ \\
Blend (6) & $7.82 \pm 1.47^{\mathrm{a}}$ & $6.88 \pm 1.64^{\mathrm{ab}}$ & $6.79 \pm 1.53^{\mathrm{ab}}$ & $6.79 \pm 1.27^{\mathrm{ab}}$ & $6.98 \pm 1.15^{\mathrm{a}}$ \\
Blend (7) & $6.75 \pm 1.36^{\mathrm{b}}$ & $6.21 \pm 0.75^{\mathrm{ab}}$ & $6.59 \pm 1.09^{\mathrm{b}}$ & $6.79 \pm 1.03^{\mathrm{ab}}$ & $6.77 \pm 0.93^{\mathrm{ab}}$ \\
Blend (8) & $7.00 \pm 1.51^{\mathrm{ab}}$ & $6.86 \pm 1.68^{\mathrm{ab}}$ & $6.50 \pm 1.41^{\mathrm{b}}$ & $6.50 \pm 1.60^{\mathrm{b}}$ & $6.86 \pm 1.57^{\mathrm{ab}}$ \\
Blend (9) & $7.15 \pm 1.39^{\mathrm{a}}$ & $6.71 \pm 0.95^{\mathrm{ab}}$ & $6.50 \pm 1.31^{\mathrm{b}}$ & $6.94 \pm 1.27^{\mathrm{ab}}$ & $6.63 \pm 1.41^{\mathrm{ab}}$ \\
Blend (10) & $6.00 \pm 1.26^{\mathrm{bc}}$ & $6.50 \pm 1.76^{\mathrm{ab}}$ & $6.00 \pm 1.15^{\mathrm{bc}}$ & $6.17 \pm 1.17^{\mathrm{b}}$ & $6.29 \pm 1.30^{\mathrm{b}}$ \\
Blend (11) & $7.50 \pm 1.26^{\mathrm{a}}$ & $7.21 \pm 1.52^{\mathrm{a}}$ & $6.86 \pm 1.68^{\mathrm{ab}}$ & $6.75 \pm 1.58^{\mathrm{ab}}$ & $6.92 \pm 1.55^{\mathrm{a}}$ \\
Blend (12) & $6.29 \pm 0.76^{\mathrm{b}}$ & $6.57 \pm 1.27^{\mathrm{ab}}$ & $5.83 \pm 0.98^{\mathrm{c}}$ & $5.75 \pm 0.71^{\mathrm{c}}$ & $6.21 \pm 1.07^{\mathrm{b}}$ \\
Blend (13) & $7.29 \pm 0.49^{\mathrm{ab}}$ & $6.71 \pm 0.76^{\mathrm{ab}}$ & $6.00 \pm 0.89^{\mathrm{abc}}$ & $6.57 \pm 0.98^{\mathrm{b}}$ & $6.14 \pm 1.07^{\mathrm{b}}$ \\
\hline
\end{tabular}

For each treatment within a column, means not sharing the same alphabetical letter are significantly different at $0.05, \mathrm{SD}=$ standard error

Table 3. Chemical composition of selected vegetable juice blends

\begin{tabular}{|l|c|c|c|c|c|}
\hline Blends & $\begin{array}{c}\text { Control } \\
\text { V8 }\end{array}$ & $\begin{array}{c}\text { *Blend } \\
(3)\end{array}$ & $\begin{array}{c}\text { *Blend } \\
(4)\end{array}$ & $\begin{array}{c}\text { *Blend } \\
(6)\end{array}$ & $\begin{array}{c}\text { *Blend } \\
(11)\end{array}$ \\
\hline Moisture \% & 94.80 & 93.70 & 93.90 & 94.00 & 94.20 \\
Total solids \% & 5.20 & 6.30 & 6.10 & 6.00 & 5.80 \\
Total carbohydrates \% & 1.198 & 4.899 & 4.465 & 4.445 & 4.013 \\
Crude protein \% & 1.00 & 1.30 & 1.00 & 1.40 & 1.20 \\
Crude fibers \% & 0.70 & 0.67 & 0.72 & 0.80 & 0.76 \\
Ash \% & 0.30 & 0.40 & 0.60 & 0.60 & 0.40 \\
pH value & 4.35 & 4.80 & 4.86 & 4.93 & 5.76 \\
Total acidity as & 0.321 & 0.204 & 0.198 & 0.199 & 0.054 \\
(Citric acid) \% & 0.965 & 1.029 & 1.024 & 1.022 & 1.024 \\
Specific gravity & 5.00 & 6.10 & 6.00 & 5.80 & 5.50 \\
Brix ${ }^{\circ}$ & $1: 15.58$ & $1: 29.90$ & $1: 30.30$ & $1: 29.15$ & $1: 101.9$ \\
Brix ${ }^{\circ}$ : acid ratio & & & & \\
\hline
\end{tabular}

"Blend (3): Tomato+ Carrot + Watermelon + Rocket (5:2:2:1).

Blend (4): Tomato+ Carrot + Celery (5:4:1).

Blend (6): Tomato+ Carrot + Parsley $(5: 4: 1)$.

Blend (11): Carrot + Watermelon +Pumpkin + Celery + Parsley (4:2:2:1:1.)

Control: (imported commercial vegetable juice). 
Table 4. Antioxidant content of the selected vegetable juice blends $(\mathrm{mg} / 100 \mathrm{ml})$ on fresh weight basis

\begin{tabular}{|l|c|c|c|c|c|c|}
\hline Constituents & $\begin{array}{c}\text { Control } \\
\text { V8 }\end{array}$ & $\begin{array}{c}\text { Blend } \\
(3)\end{array}$ & $\begin{array}{c}\text { Blend } \\
(4)\end{array}$ & $\begin{array}{c}\text { Blend } \\
(6)\end{array}$ & $\begin{array}{c}\text { Blend } \\
(11)\end{array}$ & SD $(\sigma-1)$ \\
\hline Total Phenols & 14.70 & 15.35 & 16.65 & 15.05 & 12.55 & 1.49 \\
Total Flavonoids & 32.00 & 25.00 & 31.25 & 23.00 & 20.75 & 5.01 \\
Total Carotenoids & 11.19 & 9.39 & 7.40 & 7.69 & 12.09 & 2.08 \\
Total Chlorophyll & 27.86 & 20.11 & 19.57 & 20.09 & 52.43 & 14.08 \\
Ascorbic acid & 17.33 & 20.22 & 14.92 & 15.16 & 8.45 & 4.34 \\
\hline$r$ & & 0.919 & 0.900 & 0.278 & 0.261 & \\
\hline
\end{tabular}

Values are means $\pm S D$. $P \geq 0.05$

Table 5. Minerals content of selected vegetable juice blends (ppm)

\begin{tabular}{|c|c|c|c|c|c|}
\hline Minerals & $\begin{array}{c}\text { Control } \\
\text { V8 }\end{array}$ & $\begin{array}{c}\text { Blend } \\
(3)\end{array}$ & $\begin{array}{c}\text { Blend } \\
(4)\end{array}$ & $\begin{array}{c}\text { Blend } \\
(6)\end{array}$ & $\begin{array}{c}\text { Blend } \\
(11)\end{array}$ \\
\hline $\mathrm{Fe}$ & 3.650 & 4.150 & 4.500 & 6.200 & 4.000 \\
$\mathrm{Ca}$ & 90.100 & 89.350 & 108.650 & 66.350 & 144.700 \\
$\mathrm{~K}$ & 3425 & 2915 & 3727 & 3247 & 2644 \\
$\mathrm{Na}$ & 2437 & 3135 & 1518 & 2338 & 1579 \\
$\mathrm{Mg}$ & 382 & 358 & 372 & 311 & 420 \\
$\mathrm{Zn}$ & 1.815 & 2.085 & 2.280 & 2.255 & 2.000 \\
$\mathrm{P}$ & 30.231 & 31.760 & 34.842 & 33.629 & 32.767 \\
\hline
\end{tabular}

${ }^{*}$ For explanation see Table (3).

magnesium had the highest contents (144.70 and 420 ppm, respectively), compared to those detected in the other blends (Table 5). Finally, it could be concluded that, all selected blends had adequate minerals contents and could be considered as good sources of minerals for human nutrition.

5- Effect of storage period on the chemical composition of selected vegetable juices blends

The data presented in Table (6) illustrate the effect of storage at $5 \pm 1^{\circ} \mathrm{C}$ for 3 months on the chemical composition of selected vegetable juice blends. The obtained results indicate that, moisture, total solids, total carbohydrate, crude protein, crude fiber and ash contents of all selected blends showed negligible changes during storage. Those results are in agreement with those of Abd El-Latif et al (1995); Bock et al (1998) and Mandeep and Hira (2001). The $\mathrm{pH}$ values of all selected vegetable juice blends decreased after storage. Concerning the total acidity, significant increase could be detected throughout the storage period up to three months (Table 6). From the same table, it could be also noticed that insignificant increase in specific gravity of all blends could be referred to the effect of storage period under cooling temperature. On the other hand, the ascorbic acid content, Brix ${ }^{\circ}$ and Brix ${ }^{\circ}$ : acid ratio in all blends decreased gradually during storage. These results are in accordance with those reported by Bock et al (1998) and Mandeep and Hira (2001). Finally, it could be 
Table 6. Effect of storage period on the chemical composition of selected vegetable juices blends

\begin{tabular}{|c|c|c|c|c|c|c|c|c|c|c|c|c|c|}
\hline \multicolumn{2}{|c|}{ Storage period } & \multirow{2}{*}{ 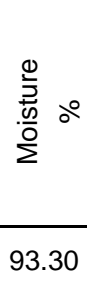 } & \multirow{2}{*}{$\begin{array}{l}\frac{0}{0} \\
\frac{0}{0} \\
\frac{0}{\pi} \\
\frac{\pi}{0}\end{array}$} & \multirow{2}{*}{ 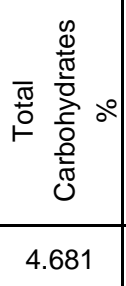 } & \multirow{2}{*}{ 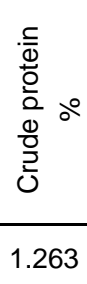 } & \multirow{2}{*}{ 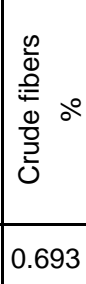 } & \multirow{2}{*}{$\begin{array}{l}\frac{c}{4} \circ \circ \\
0.389\end{array}$} & \multirow{2}{*}{$\begin{array}{l}\frac{0}{\frac{D}{T ⿰}} \\
\stackrel{T}{\frac{1}{2}} \\
4.60\end{array}$} & \multirow{2}{*}{ 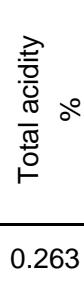 } & \multirow{2}{*}{ 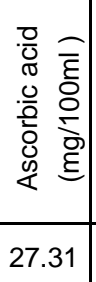 } & \multirow{2}{*}{ 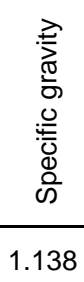 } & \multirow{2}{*}{$\begin{array}{l}\stackrel{\stackrel{0}{x}}{\bar{m}} \\
6.83\end{array}$} & \multirow{2}{*}{ 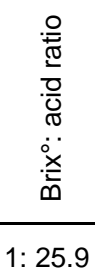 } \\
\hline & 3) & & & & & & & & & & & & \\
\hline 亳 & Blend (4) & 93.60 & 6.40 & 4.381 & 1.000 & 0.706 & 0.563 & 4.13 & 0.252 & 24.00 & 1.163 & 6.00 & 1: 23.8 \\
\hline & Blend (6) & 93.80 & 6.20 & 4.321 & 1.341 & 0.753 & 0.566 & 4.62 & 0.243 & 26.31 & 1.122 & 6.31 & $1: 25.9$ \\
\hline & $\mathrm{B}$ & 0 & 6.10 & 4.001 & 0 & 77 & 38 & 0 & 3 & 4.03 & $T$ & 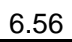 & 1.637 \\
\hline \multirow{4}{*}{ 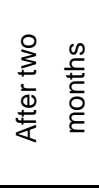 } & P) & .10 & 90 & 0 & 0 & 696 & 86 & 4.15 & 86 & 33 & 6 & $.7 \varepsilon$ & 1.20 .1 \\
\hline & Blend (4) & 93.50 & 6.50 & 4.231 & 1.010 & 0.763 & 0.571 & 4.00 & 0.275 & 22.08 & 1.182 & 6.00 & $1: 21.8$ \\
\hline & Blend (6) & 93.60 & 6.40 & 4.311 & 1.331 & 0.771 & 0.567 & 4.32 & 0.263 & 24.52 & 1.136 & 6.25 & $1: 23.8$ \\
\hline & Blend & 93.80 & 6.20 & 0 & 1.200 & 0.783 & 0.391 & 5.00 & 0.169 & 22.13 & 1.141 & 38 & $1: 37.8$ \\
\hline \multirow{4}{*}{ 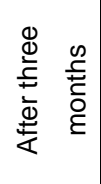 } & Blend (3) & 93.00 & 7.00 & 4.321 & 1.235 & 0.710 & 0.378 & 4.00 & 0.291 & 23.36 & 1.231 & 6.69 & $1: 22.9$ \\
\hline & Blend (4) & 93.50 & 6.50 & 4.000 & 1.00 & 0.766 & 0.563 & 3.61 & 0.293 & 22.00 & 1.263 & 5.89 & $1: 20.1$ \\
\hline & Blend (6) & 93.60 & 6.40 & 4.010 & 1.329 & 0.778 & 0.562 & 4.00 & 0.281 & 23.00 & 1.233 & 6.18 & $1: 22.1$ \\
\hline & Blend(11) & 93.70 & 6.30 & 3.821 & 1.183 & 0.793 & 0.383 & 4.33 & 0.173 & 21.62 & 1.251 & 6.33 & $1: 36.3$ \\
\hline
\end{tabular}

Blend (3): Tomato+ Carrot + Watermelon + Rocket (5:2:2:1)

Blend (4): Tomato+ Carrot + Celery $(5: 4: 1)$.

Blend (6): Tomato+ Carrot + Parsley (5:4:1).

Blend (11): Carrot + Watermelon +Pumpkin + Celery + Parsley (4:2:2:1:1.)

Control : (exported commercial vegetable juice).

concluded that, insignificant differences in chemical composition of selected vegetable juice blends could be detected throughout the storage period under refrigeration up to three months.

\section{6- Microbiological examination}

The best blends were evaluated microbiologically (total count, coliform and molds and yeast) during storage at $5 \pm 1^{\circ} \mathrm{C}$ for 3 months as shown in the data presented in Table (7). The results indicate that, no microbial growth was detected after processing or during storage. Minor contamination especially in the blend (4) occurred during the packaging process and its microbial count increased slightly and gradually during storage (Table 7). Meanwhile, all products maintained its original sensory properties. This might be due to the effect of thermal treatments, blanching and pasteurization, during processing which reduced the activity of microorganisms during storage. All samples were coliform free till the end of storage period.
Table 7. Effect of storage period on total viable counts of selected vegetable juice blends (cfu/ml)

\begin{tabular}{|l|c|c|c|c|}
\hline \multirow{2}{*}{$\begin{array}{c}\text { Vegetable } \\
\text { blends }\end{array}$} & \multicolumn{4}{|c|}{ Storage period } \\
\cline { 2 - 5 } & $\begin{array}{c}\text { Zero } \\
\text { time }\end{array}$ & $\begin{array}{c}\text { After one } \\
\text { month }\end{array}$ & $\begin{array}{c}\text { After two } \\
\text { months }\end{array}$ & $\begin{array}{c}\text { After three } \\
\text { months }\end{array}$ \\
\cline { 2 - 5 } & \multicolumn{4}{|c|}{ Total microbial count $\times 10^{2}$} \\
\hline Blend (3) & $<10^{2}$ & $<10^{2}$ & $<10^{2}$ & $<10^{2}$ \\
Blend (4) & 1.398 & 2.954 & 3.038 & 3.112 \\
Blend (6) & 1.204 & 2.408 & 2.602 & 2.796 \\
Blend(11) & 1.041 & 2.082 & 2.602 & 3.038 \\
\hline
\end{tabular}

\section{REFERENCES}

Abdel-Latif Somia, H.; H.M. Radwan and F.A. ElAshwah (1995). Production of non-hydroscopic tomato powder. Annals Agric. Sci., Moshtohor, 33(2): 729-743.

Amy, R.B.; Qi Dai; W. Yougui; C.J. James and B.L. Eric (2005). Consumption of fruit and vegeta- 
ble juices predicts a reduced risk of Alzheimer's disease. Alzheimer's and Dementia, 1(1): 60-61. A.O.A.C. (1998). Official Methods of Analysis of The Association of Official Analytical Chemists. $15^{\text {th }}$ Ed. Arlington Virgenia U. S. A.

Barba Olives, A.I.; M. Camara Hurtado; M.C. Sanchez Mata; V. Fernandez Ruiz and M. LÒpez Sáenz (2006). Application of a UV-vis detection HPLC method for a rapid determination of lycopene and $\beta$-carotene in vegetables. Food Chem., 95(2): 328-336.

Bock, H.P.; A.K. Hyun; H.P. Young and Y.O. Bong (1998). Change in physicochemical components of stewed pumpkin juice heated and stored under different conditions. J. Korean Society of Food Sci. and Nutr., 27(1): 1-9.

Djuric, Z. and K.C. Powell (2001). Antioxidant capacity of lycopene containing foods. International J. Food Sci. Nutr., 52(2): 143-149.

El-Bastawesy, Amal M.; E.R. Sheashea and S.H. Hamed (2003). Studies on aroma compounds of apricot- carrot nectar. Egypt. J. Agric. Res., 81(4): 1761-1781.

Johanna, W.L. (1999). Health effects of vegetables and fruits: Assessing mechanisms of action in human experimental studies. Am. J. Clin. Nutr. 70: 475-490.

KähkÖnen, M.P.; A.I. Hopia; H.J. Vuorela; J.P. Rauha; K. Pihlaja; T.S. Kujala and M. Heinonen (1999). Antioxidant activity of plant extracts containing phenolic compounds. J. Agric. Food Chem., 47: 3954-3962.

Kasai, M.; N. Okamoto; K. Hatne and A. Shimada (1997). Role of calcium and magnesium ions in the hardening of pressure-treated root vegetables. J. Agric. Food Chem. 45: 599-605.

Lindley, M.G.; P.K. Beyts; I. Caanales and F. Borrego (1993). Flavor modifying characteristics of the intense sweetener neohesperidin dihydrochalcone. J. Food Sci. 58: 592-599.

Mandeep-Dhaliwal and C.K. Hira (2001). Effect of storage on physico-chemical and nutritional characteristics of carrot-beetroot and carrot-black carrot juices. J. Food Sci. and Tech., India, 38(4): 343347.

Marco, R.; D. Mario; L. Cristina; P. Adele; G. Stefano and G. Gabriella (2002). Antiradical activity of water soluble components in common diet vegetables. J. Agric. Food Chem., 50: 12721277.

Morris, M.C.; D.A. Evans; C.C. Tangney; J.L. Bienias and R.S. Wilson (2006). Associations of vegetable and fruit consumption with age-related cognitive change. Neurology, 67: 1370-1376.
Ninnart, C.; T. Nattapol; P. Piyaanong and D. Visanu (2002). Mixed vegetable and fruit high fiber jelly drink: effects of carrot, pineapple and pumpkin proportions on physical, chemical and sensory characteristics. Thai J. Agric. Sci., 35(2): 213222.

Ranganna, S. (1979). Handbook of Analysis and Quality Control for Fruit and Vegetable Products. $2^{\text {nd }}$ Ed. Chapter 28, pp. 888-924, Fruit Juices, Concentrates and Beverages., Tata Mc Graw- Hill Publishing Co., Limited, New Delhi.

Rao, A.V. (2002). Lycopene, tomatoes and the prevention of coronary heart disease. Experimental Bio. Med., 227(10): 908-913.

Rodriguez-Bernaldo, Q. Ana and S. Costa Helena (2006). Analysis of carotenoids in vegetable and plasma samples. J. Food Composition Analysis, 19(2-3): 97-111.

Ruel, G.; P. Sonia; C. Patrick; L. Benoìt and C. Charles (2005). Changes in plasma antioxidant capacity and oxidized low density lipoprotein levels in men after short- term cranberry juice. Metabolism, 54(6): 856-861.

Shi, J. and M. Le Maguer (2000). Lycopene in tomatoes: chemical and physical properties affected by food processing. Critical Reviews in Biotechnology, 20(4): 293-334.

Sook Lee, H.; J. Jae In; Y. Hee- Kang; F. Khachik and J. Han Yoon Park (2003). Affect of lycopene on the insulin-like growth factor-I receptor signaling pathway in human colon cancer HT-29 cells. J. of Korean Society Food Sci. Nutr., 32(3): 437-443.

Steel, R.G. and T.H. Torrie (1980). Principles and Procedures of Statistics. Abiometrical Approach. McGraw Hill Book Comp., Inc., New York, USA.

Steinmetz, K.A. and J.D. Potter (1991). Vegetables, fruits and cancer, 11 Mechanisms. Cancer Causes Control, 2: 427-442.

Takeoka, G.R.; Dao Lan; S. Flessa; D.M. Gillespie; W.T. Jewell; B. Huebner; D. Bertow and S.E. Ebeler (2001). Processing effects on lycopene content and antioxidant activity of tomatoes. J. Agric. Food Chem., 49(8): 3713-3717.

Vonderzant, C. and D.F. Splittstoesser (1992). Compendium of Methods for The Microbiological Examination of Foods. American Public Health Assoc., Washington DC., USA.

Weisburger, J.H. (1999). Mechanisms of action of antioxidants as exemplified in vegetables, tomatoes and tea. Food Chemical Toxicology, 37(910): 943-948. 